\title{
PRELIMINARY STUDYON THE CONTROL OF WESTERN FLOWER THRIPS, Frankliniella occidentalis (PERGANDE)IN PEPPER CROP GREEN HOUSES IN QALYUBIA GOVERNORATE, EGYPT. \\ Shalaby H. H. \\ Plant Protec., Res,. Inst., (PPRI), Agric., Res., Center (ARC), Dokki \\ 12618, Giza, Egypt. \\ E. Mail: hassan_shalaby2003@yahoo.com
}

\begin{abstract}
Rotation of three compounds and in combination of additional control method(i.e., blue sticky traps)were conducted under greenhouse pepper conditionsduring 2013 and 2014 seasons at Kaha region, Qalyubia Governorate to get successful results in Frankliniella occidentalis Pergande (WFT)control and reduce damage to pepper flowers. Two greenhouse G2 and G3 were treated at weekly intervals with three compounds (i.e., Sumithion $50 \%$ ECat $250 \mathrm{~cm}^{3} / 100 \mathrm{~L}$; Radiant $12 \%$ SC at $25 \mathrm{~cm}^{3} / 100 \mathrm{~L}$ and mixture of two plant extracts,Artemisia annua L. and Capsicum annuum, L. at the ratio of $1: 1$ at $300 \mathrm{~cm}^{3} / 100 \mathrm{~L}$ )while, blue sticky traps at 20 traps/greenhouse were installed only in G3starting from July $2^{\text {nd }}$ week for both seasons to accelerate the efficiency of foliage sprays against WFT attacks on pepper flowers. During the investigation period, no crop damage was detectedon the pepper leaves by WFT. The absence of WFT population from leaf samples due to the flowers were more attractive than the leaves. The infestation trends of the western flower thrips (WFT) $F$. occidentalis on pepper flower samples showed low levels during the second half of late June in both seasons (in control greenhouse G1). Afterward and in mid-August the flower damage was detected where they feed on flower tissues and pollen and failure in hybridization Balady var. and hybrid 08. WFT population declined coincides by the decrease in flowers numbers of pepper plants during September confirming that WFT preferred flowers of pepper greenhouse than leaves. Also, results indicated that, using rotation of different compounds and in combination of additional control method such as blue sticky traps gave successful effects in WFT control under greenhouse pepper conditions and reduced damage to pepper flowers resulting from infestation by $F$. occidentalis.

Keywords: Frankliniella occidentalis, western flower thrips, pepper greenhouse;control; Fenitrothion; Spinetoram; plant extract; blue sticky traps.
\end{abstract}

\section{INTRODUCTION}

Western flower thrips (WFT), Frankliniella occidentalis (Pergande 1895) (Thysanoptera; Thripidae), originates from California in the USA, and is a very harmful thrips species. Since the 1960's, it had a limited dispersion in the northwestern USA, Canada and Mexico. However, it has spread to many countries around the world since the 1970's (Anonymous 2002; Kirk \& Terry 2003). In Tunisia, WFT is still considered to be a quarantine pest following its introduction in the early 1990's due to indirect damage caused by the transmission of viruses such as Tomato spotted wilt virus (TSWV) and impatiens necrotic spot wilt virus (INSWV) (Elimem et al. 2014). WFT is a polyphagous thrips species that may attack a large range of plant species belonging to several botanical families (Belharrath et al. 1994; Kirk 2001; Kirk 
\& Terry 2003; Cloyd 2009). In Egypt, El-Wakkad (2007)recorded and identified WFT ( $F$. occidentalis) on flowers of five fruit varieties, apple, citrus, grape, guava and mango also, he stated that, sky-blue color trap was the most attractive color to thrips. In addition, $F$. occidentaliswas the most dominant species in apple, citrus and mango followed by Thrips tabaci.

The control of WFT is possible by various means even though this pest is usually controlled by insecticides. However, this pest is able to acquire some resistance to several insecticide families, making chemical treatments ineffective. Thus, the alternation of different insecticides every 2-3 weeks is strongly recommended, although this depends on the biology of the pest, the season, environmental factors and the number of WFT generations (Grasselly1996; Shelton et al. 2003, 2006). The majority of the thrips species attacking flowers in particular, including $F$. occidentalis, prefer white traps that have a better reflection of light than other trap colours such as blue or yellow (Hoddle et al.2002). However, Roditakis et al. (2001) noted that trap colours that are the most attractive to WFT are blue and fuchsia rather than yellow or other trap colours. Sticky traps, however, seem to be an effective way to control and monitor WFT populations. For instance, the use of yellow sticky traps in cucumber greenhouses attracted a large number of WFT adults and could be used to directly control or monitor WFT populations (Zepa-Coradini et al. 2010).Sampson et al.(2012) indicated that thrips in general (and WFT in specific) use scent and colour to find host flowers. For this reason, the choice of trap colour is important to catch WFT. In fact, among many trap colours that were used by Sampson et al. (2012), blue sticky traps caught the highest number of WFT with highly significant differences between yellow, clear and black traps.

Trials conducted in this work aimed to use rotation of different compounds and in combination of alternative control way such as blue sticky traps to get successful results in WFT control under greenhouse conditions. Available literature revealed that there is a shortage of knowledge about this pest upon vegetables and pepper flowers were recorded as a new host for $F$. occidentalis for the first time in Egypt so, the present work aimed to study the following aspects:

- $\quad$ To know the species present in pepper (Capsicum annuum) flowers in order to make management decisions because the WFT occur in large numbers in the flowers

- The proper way for controlling the western flower thrips ( $F$. occidentalis) to provide the highest level of control.

Next step: Study the occurrence of the Western Flower Thrips, Frankliniella occidentalis on vegetable host plants in Egypt.

\section{MATERIALS AND METHODS}

Three greenhouses with area of $540 \mathrm{~m}^{2}$ each, were cultivated by new local pepper hybrid 08 beside the commercial variety Balady. The hybrid 08 and the variety Balady were transplanted in double rows of plants with $50 \mathrm{~cm}$ spacing between and within rows. The hybrid 08 was obtained from Horticulture Research Institute, Ministry of Agric. The seedlings were cultivated on March 20, 2013 and on April 1, 2014. The plants of this 
experiment received all normal recommended agricultural practices of pepper under greenhouse conditions except for the studied variant.

Experimental site: Kaha Research Station at Qalyubia, Horticulture Research Institute.

Tested pest: The western flower thrips (WFT) Frankliniella occidentalis (Pergande, 1895), (Thysanoptera: Thripidae) adult and larval stage.

A few flowers collected periodically during the experimentation period and placed in a small container with $70 \%$ alcohol. The container can be shaken to dislodge the thrips, which can then be examined under a microscope to identify the species. The samples of (WFT) were identified by Insect Classification Dept., Plant Protection Research Institute, Dokki, Giza, Egypt.

Tested Treatments:

1-Fenitrothion(Sumithion $50 \%$ EC) distributed by Sumitomo, Egypt.

2 -Spinetoram (Radiant 12\% SC), distributed by Shoura Company, Egypt.

3- The plant extract,Artemisia annua L. (Asteraceae) methanolic extract and Capsicum annuum, L. (Solanaceae) ethanolic extract mixture at the ratio 1:1(Reda et al.2014).

4- Blue sticky traps, $17.5 \times 26.5 \mathrm{~cm}^{2}$. The traps changed weekly. Application rates: Test materials were applied at labeled rates as follows:

1- Fenitrothion (Sumithion $50 \% \mathrm{EC}$ ) at $250 \mathrm{~cm}^{3} / 100 \mathrm{~L}$.

2-Spinetoram (Radiant $12 \% \mathrm{SC}$ ) at $25 \mathrm{~cm}^{3} / 100 \mathrm{~L}$.

3- The plant extract,Artemisia annua L. (Asteraceae) methanolic extract and

Capsicum annuum, L. (Solanaceae) ethanolic extract mixture at the ratio 1:1 at $300 \mathrm{~cm}^{3} / 100 \mathrm{~L}$.

4- Blue sticky traps, $17.5 \times 26.5 \mathrm{~cm}^{2}$ at 20 traps per greenhouse.

Treatment procedures:

Three pepper greenhouses were used:

1- Control greenhouse 1 (with (50\% of the area) and without traps (50\% of the area));

2- Greenhouse treated with weekly rotation of the three compoundsG2;

3- Greenhouse treated with weekly rotation of the three compoundsplus 20 blue sticky trapsG3.

In control greenhouse G1, populations of thrips (adults \& larvae) on the leaves were monitored by direct investigation of 50 pepper leaves randomly chosen from 50 plants per greenhouse. While, the populations of thrips in flower samples were monitored by collecting samples of 50 flowers randomly chosen from 50 plants per greenhouse, put into paper bag and counted in the laboratory starting from June $3^{\text {rd }}$ week. In addition, populations of thrips attracted on blue sticky traps were recorded starting from July, $3^{\text {rd }}$ week for both seasons. All samples were counted in weekly intervals till early September for both seasons.

To explore the highest level of $F$. occidentalis control, two trials were conducted in $\mathrm{G} 2$ and $\mathrm{G} 3$ :

A. Greenhouse treated with weekly rotation of the three compounds $G 2$.

B. Greenhouse treated with weekly rotation of the three compounds in combination of installation of blue sticky traps G3. 
Application of the compounds started from late June while blue sticky traps were installed starting from July, $2^{\text {nd }}$ week for both seasons. Weekly samples of 50pepper flowers were collected randomly per greenhouse from treated plants.

The number of thrips in the flowers determined by picking the flower and placing it on a white board. Gently tear open the flower so that the thrips will emerge onto the board where the adults and larvae can be readily distinguished and counted (Funderburk 2011).

The density of adult thrips was also sampled weekly by counting the catches on blue sticky traps $\left(17.5 \times 26.5 \mathrm{~cm}^{2}\right.$ each) placed about $50 \mathrm{~cm}$ over the top of the plants and changed weekly. 20 traps per greenhouse were placed.

To compare the effect of different treatments on the number of $F$. occidentalis, a reaction coefficient $(\mathrm{Wr} \%)$ was calculated using the following formula:

$$
\mathbf{W r}=\frac{N P \times 100}{N K}-\mathbf{1 0 0}
$$

Where:

$\mathrm{Wr}=$ reaction coefficient.

NP = average of the treated replicates.

NK = average of untreated replicates.

The positive values of the coefficient show the percent by which the studied treatment was higher than control and negative ones show the percent by which it was lower (Ignatowicz, 1979).

\section{RESULTS AND DISCUSSION}

\section{Infestation trends of the western flower thrips (WFT) Frankliniella occidentalis:}

As it was observed on protected pepper in G1 (Control greenhouse) during 2013 and 2014 in Kaha, Qalyubia the infestation trends of $F$. occidentalis adults and larval stages on the leaves, thrips started to appeared on the plant during the second half of May-early June in both 2013 and 2014. The mean number of thrips per leaf gradually increased with a population peak of 3.8 and 4.1 thrips per leaf during the second half and late June in both seasons respectively. During this period, no crop damage was detected. A rapid decline followed and continued by time laps until late July where WFT were absent from leaf samples (Fig.1).

The absence of WFT population from leaf samples may be attributed to the reason that the flowers were more attractive than the leaves where, WFT adults preferentially fly toward and land on flowers and that, thrips populations do not increase very much on pepper leaves during late June coincides with beginning of flowering stage .Similarly to what observed by Tommasini and Maini (2002)where they stated that; Thrips were found on leaves occasionally, confirming that sweet pepper flowers are more attractive for thrips, both adults and nymphs, than leaves, so we suggest to sample just the flowers to monitor thrips on sweet pepper. 
In the present study, The infestation trends of the western flower thrips (WFT) F. occidentalis on pepper flower samples showed low levels during the second half of late June in both 2013 and 2014. Afterward and within two months, the WFT population occurrence reached its peak by 4.9 and 5.1 thrips/flower during mid-August in both seasons, respectively (Fig. 1). During this period and through late August-mid Sept. the flower damage was detected where they feed on flower tissues and pollen.

Pollen feeding greatly increases the number of eggs produced.Furthermore, they indirectly damage plants by transmitting tospoviruses such as tomato spotted wilt virus (Yang et al. 2012). WFT feed on petals and other flower structures. Thrips feed by sucking the contents of the epidermal cells of the plant(Funderburk 2011).

The WFT population levels in flower samples decreased after its peak during mid-August to late Sept. counted 1.0 thrips/flower in both seasons. This decline in population coincides by the decrease in flowers numbers of pepper plants and the day-time temperature during September. In general, $F$. occidentalis preferred flowers of pepper greenhouse than leaves. Also Berlinger et al. (1997) found that $F$. occidentalis is first attracted by flower than leaves. On the contrary, Higgins (1992) found in British Columbia (Canada) that more than $85 \%$ of nymphs of $F$. occidentalis were recorded on leaves of sweet pepper, while females preferred to stay within flowers (84-95\%). Garcia-Marì et al. (1994) found that both nymphs and adults of thrips have to be monitored in order to have a good estimation of the infesting population, and that an average of 100 flowers of a vegetable crop have to be observed to estimate pest population.

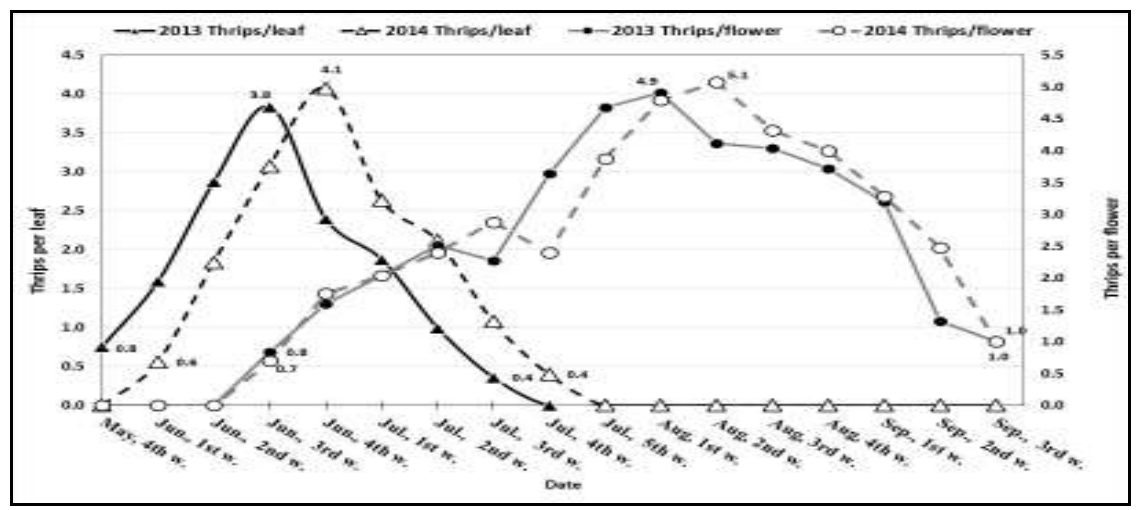

Fig (1): Infestation trends of Frankliniella occidentalis adults and larval stages in the leaves and flower samples in pepper greenhouse during 2013 and 2014 in Kaha, Qalyubia. 


\section{Development of thrips population in sampled pepper leaves affected by two treatments:}

The two greenhouses G2 and G3 were treated with Spinetoram and the plant extract. Spinetoram applied to pepper greenhouse just at the first occurrence of WFT on leaves starting from mid-June during 2013 and late June during 2014. One week later, the plant extract was applied to the plants. The application of the two treatments to pepper affected thrips population on leaves resulting in average of 0.0 thrips/leaf over the two weeks from treatments while, the untreated plants $(\mathrm{G} 1)$ had a peak of $2.4 \& 2.6$ thrips/leaf for the two seasons, respectively. Thrips population had a rapid decline followed and continued by time laps until late July where WFT were absent from leaf samples. According to equation of (Ignatowicz, 1979), the population of WFT on the leaves was decreased by 62.0 and $63.0 \%$ for the two seasons, respectively than the control treatment (Fig. 2 and Table 1). Generally, the two treatments were satisfied to manage WFT on pepper greenhouse on leaves and before the population was attracted to the flowers.WFT is primarily associated with flowers, non-flower plant parts such as leaves and stems were kept to a minimum in samples during the bloom periods (Eugene and David 2011).

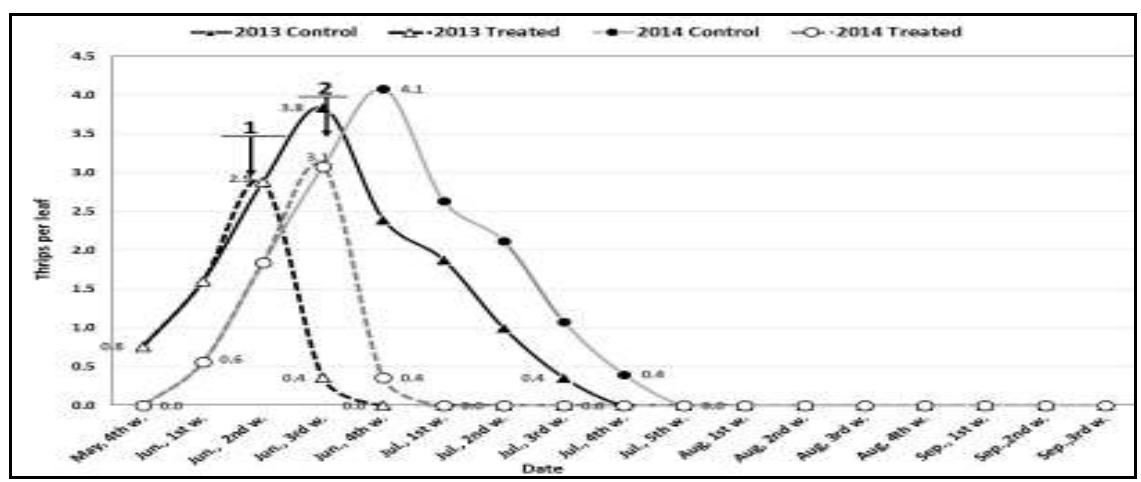

Fig. (2): Mean no. of Frankliniella occidentalis per leaf in greenhouse in which was controlled by insecticides: Legend of treatments: 1= Spinetoram; 2= Plant extract, during 2013 and 2014 in Kaha, Qalyubia.

Development of thrips population in sampled pepper flowers affected by different treatments:

In this study, greenhouse G2 and G3 were treated at weekly intervals with three compounds (i.e., Fenitrothionat $250 \mathrm{~cm}^{3} / 100 \mathrm{~L}$; Spinetoram at 25 $\mathrm{cm}^{3} / 100 \mathrm{~L}$ and Mixture of two plant extracts, Artemisia annua L. and Capsicum annuum, L. at the ratio of $1: 1$ at $300 \mathrm{~cm}^{3} / 100 \mathrm{~L}$ ). The foliage spray of the treatments were used weekly in rotation beginning of the $3^{\text {rd }}$ week of June 
(first of flowering stage). While blue sticky traps at 20 traps/greenhouse were installed only in G3starting from July $2^{\text {nd }}$ week for both seasons to accelerate the efficiency of foliage sprays against WFT attacks on pepper flowers. Elimem et al. (2014) mentioned that, the control of WFT is possible by various means even though this pest is usually controlled by insecticides. However, this pest is able to acquire some resistance to several insecticide families, making chemical treatments ineffective. Thus, the alternation of different insecticides every 2-3 weeks is strongly recommended.Also he stated that, blue sticky traps with and without pheromone capsules were used to monitor and control Frankliniella occidentalis Pergande (1895) (Thysanoptera; Thripidae) in pepper crop greenhouses in Tunisia. Traps containing pheromone capsules could catch significantly more thrips than those without capsules, proving their efficiency in attracting and controlling this pest. In fact, greenhouses with traps with pheromone capsules caught 585.1, 526.7, and 668.8 adults/trap in a greenhouse with 10 traps with pheromone capsules on April 12, 19, and 26, 2012, respectively. The capture in a greenhouse with five traps with pheromone capsules was about 456.2, 412.8, and 431 adults/trap while in a greenhouse with five traps without pheromone capsules, the capture of $F$. occidentalis adults numbered 198, 257, and 302 adults/trap for the same three dates.

Table. (1): Number of Frankliniella occidentalis per leaf in greenhouse in which was controlled by insecticides during 2013 and 2014 in Kaha, Qalyubia.

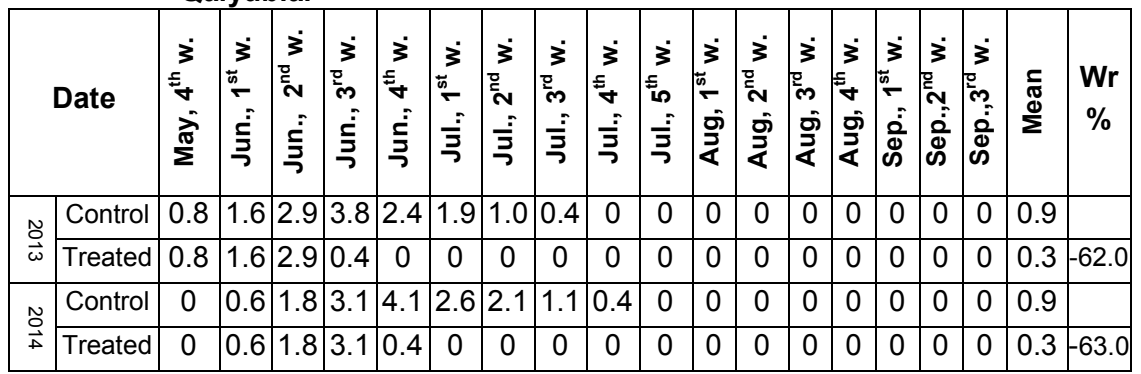

WFT catches on blue sticky traps in pepper greenhouse:

Data in (Fig. 3 \& Table 2) show the mean numbers of captured WFT adults/sticky trap/week in the greenhouse where 20 traps were installed during 2013 and 2014 in Kaha, Qalyubia. Data revealed that, blue sticky traps in control greenhouse $\mathrm{G} 1$ attracted more thrips than the traps in treated greenhouse $\mathrm{G} 3$ by a peak of $(737.8 \& 814.8)$ in $\mathrm{G} 1$ and $(554.8 \& 631.8)$ WFT adults/sticky trap/week in G3 during Aug, $1^{\text {st }}$ w. of seasons 2013 and 2014, respectively.WFT catches on blue sticky trapswas decreased by 37.8 and $32.2 \%$ during the two seasons in greenhouse G3, respectively than the control treatmentG1. This result proved that, using alternative control methods with pesticides enhanced their efficacy to reduce WFT population. Moreover, Sampson et al. (2012) reported that WFT localizes flowers by using scent and colour although blue sticky traps attracted more thrips than traps of other colours. Cloyd (2009) stated that the threshold of WFT may 
vary from 10 to 40 WFT/sticky trap/week. For Dianthus caryophyllus L., for instance, the threshold was about 20 WFT adults/blue sticky trap/week, the value that could be used to determine insecticide applications in an integrated pest control program.

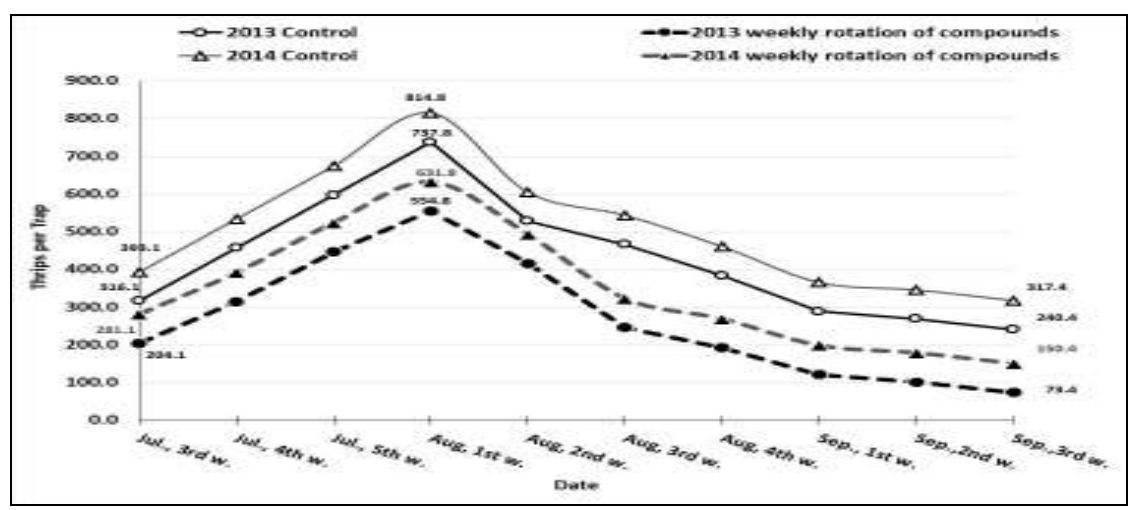

Fig. (3): Mean no. of Frankliniella occidentalisadults on blue sticky traps in the greenhouse where 20 traps were installed during 2013 and 2014 in Kaha, Qalyubia.

Table. (2): Mean no. of Frankliniella occidentalis adults on blue sticky traps in the greenhouse $\mathbf{G} 3$ where 20 traps were installed during 2013 and 2014 in Kaha, Qalyubia.

\begin{tabular}{|c|c|c|c|c|c|c|c|c|c|c|c|c|c|}
\hline & Date & $\begin{array}{l}3 \\
\frac{3}{2} \\
\frac{0}{3} \\
\bar{j}\end{array}$ & 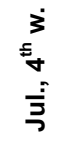 & $\begin{array}{l}3 \\
\dot{5} \\
\dot{5} \\
\dot{5} \\
\overline{5} \\
\end{array}$ & $\begin{array}{l}\frac{3}{3} \\
\frac{5}{2} \\
\frac{5}{2}\end{array}$ & 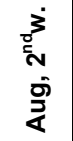 & $\begin{array}{l}3 \\
\frac{2}{2} \\
\frac{2}{3} \\
\frac{0}{4}\end{array}$ & $\begin{array}{l}3 \\
\text { 方 } \\
\frac{5}{3} \\
\frac{0}{8}\end{array}$ & $\frac{3}{3}$ & 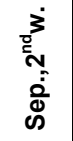 & 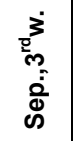 & 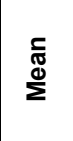 & $\sum_{3}^{\circ}$ \\
\hline \multirow{2}{*}{$\stackrel{\text { No }}{\vec{\omega}}$} & $\begin{array}{l}\text { Control } \\
\text { G1 }\end{array}$ & 316.1 & 456.7 & 597.2 & 737.8 & 527.8 & 466.3 & 383.5 & 288.3 & 268.5 & 240.4 & 440.7 & \\
\hline & $\begin{array}{l}\text { weekly rotation } \\
\text { of compounds } \\
\text { G3 }\end{array}$ & 204.1 & 314.6 & 446.6 & 554.8 & 415.8 & 245.8 & 191.8 & 121.3 & 101.5 & 73.4 & 273.9 & -37.8 \\
\hline \multirow{2}{*}{$\stackrel{\text { N }}{\stackrel{\leftrightarrow}{\perp}}$} & $\begin{array}{l}\text { Control } \\
\text { G1 }\end{array}$ & 393.1 & 533.7 & 674.2 & 814.8 & 604.8 & 543.3 & 460.5 & 365.3 & 345.5 & 317.4 & 517.7 & \\
\hline & $\begin{array}{l}\text { weekly rotation } \\
\text { of compounds } \\
\text { G3 }\end{array}$ & 281.1 & 391.6 & 523.6 & 631.8 & 492.8 & 322.8 & 268.8 & 198.3 & 178.5 & 150.4 & 350.9 & -32.2 \\
\hline
\end{tabular}

WFT population in sampled flowers in treated pepper greenhouse:

When WFT in pepper flowers was monitored in the three greenhouses, large variations and differences were observed (Fig. 4 \& Table $3)$. The greenhouse control G1 was characterized by an increase in the number of thrips/flower between July $2^{\text {nd }} \mathrm{w}$. and followed accelerating until August $1^{\text {st }} \mathrm{w}$. by a peak of $(4.9 \& 4.0)$ and $(5.1 \& 4.1)$ thrips/flower for untreated and plants treated with traps only during 2013 and 2014, respectively. Also, the WFT population in greenhouse G2 \& G3 was considerably continued accelerate in spite of the foliage sprays of the used 
compounds although, it was necessary to use alternative control method for population reduction.

However the combined use of rotation the three compounds and blue sticky traps all resulted in a significant decrease in the number of WFT per flower starting from July $3^{\text {rd }}$ week until the end of the study on Sept. $3^{\text {rd }}$ week. Grand mean population of WFT during the sampling period in greenhouse G2 which treated with the three compounds was intermediate $(1.6 \& 1.5$ thrips/flower) while, mean population of WFT in greenhouse G3 was considerably low ( $1.1 \& 1.1$ thrips/flower) compare with untreated greenhouse G1 which was high (2.9 \& 2.9 thrips/flower). The number of thrips/flower was decreased by $(24.0,42.6$ and $59.9 \%)$ during 2013 and by $(21.4,48.7$ and $63.5 \%$ ) during 2014 for blue sticky traps $\mathrm{G} 1$, weekly rotation of compounds G2 and weekly rotation of compounds in combination of traps G3, respectively than the control treatment.
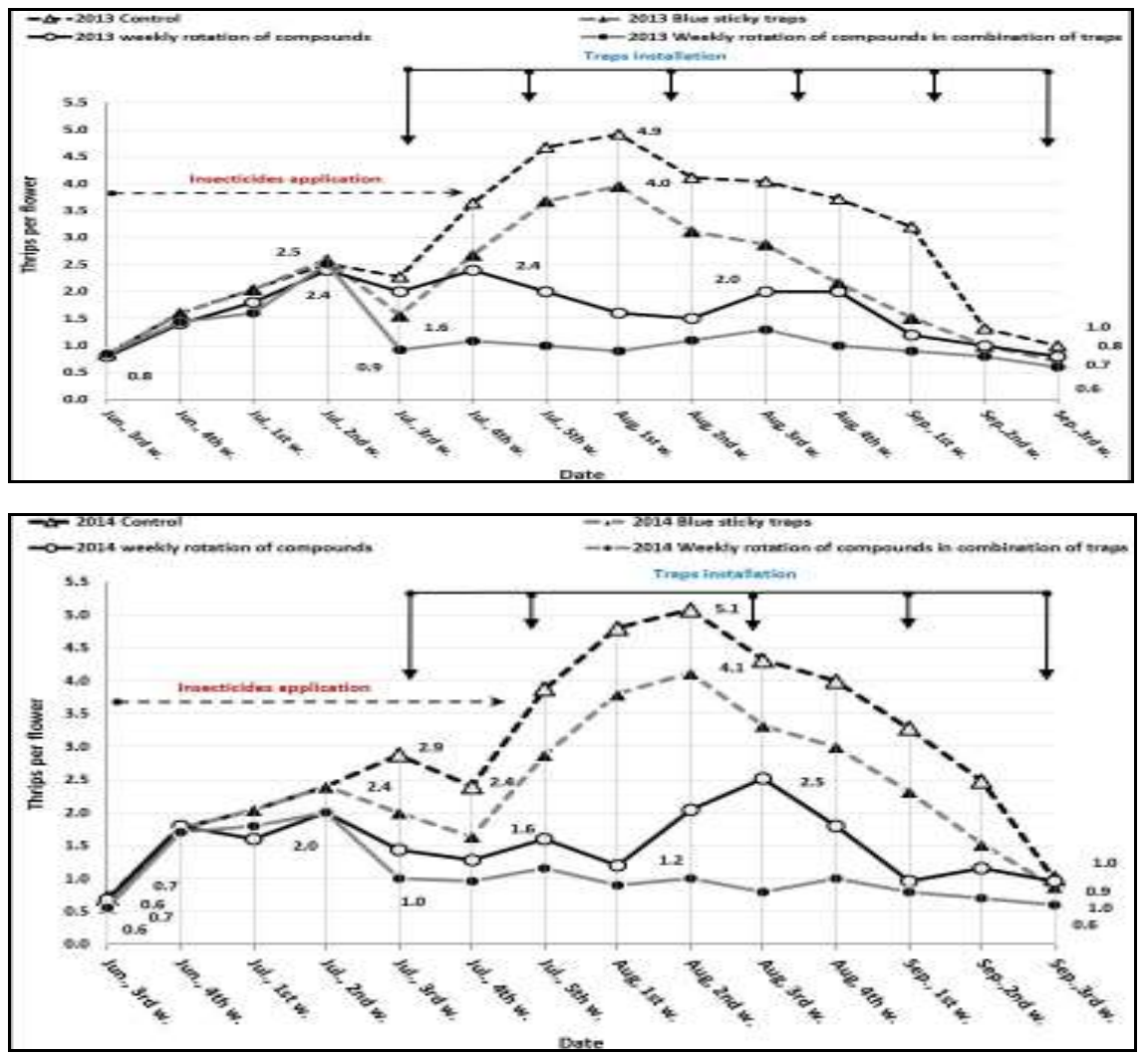

Fig. (4): Mean no. of Frankliniella occidentalis adults and larval stages in the flower samples in greenhouse in which was controlled by "different compounds and installation of blue sticky traps" during 2013 and 2014 in Kaha, Qalyubia. 
Table (3): Mean number of Frankliniella occidentalis adults and nymphal stage in the flower samples in greenhouse in which was controlled by "different compounds and installation of blue sticky traps" during 2013 and 2014 in Kaha, Qalyubia.

\begin{tabular}{|c|c|c|c|c|c|c|c|c|c|c|c|c|c|c|c|c|}
\hline Date & 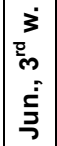 & \begin{tabular}{c}
3 \\
\multirow{2}{z}{} \\
$\dot{5}$ \\
5 \\
5
\end{tabular} & 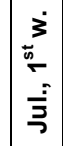 & 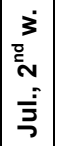 & 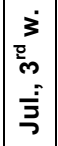 & $\begin{array}{c}3 \\
\vdots \\
5 \\
5 \\
\vdots \\
5 \\
5\end{array}$ & 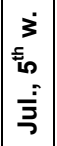 & 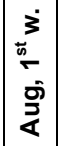 & 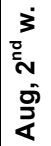 & 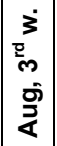 & 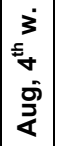 & $\begin{array}{c}3 \\
\dot{3} \\
\dot{n} \\
\vdots \\
\dot{0} \\
\dot{0}\end{array}$ & 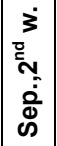 & $\begin{array}{l}3 \\
\vdots \\
0 \\
0 \\
0 \\
0 \\
0 \\
0\end{array}$ & 胥 & Wr\% \\
\hline Control G1 & 0.8 & 1.6 & 2.0 & 2.5 & 2.3 & 3.6 & 4.7 & 4.9 & 4.1 & 4.0 & 3.7 & 3.2 & 1.3 & 1.0 & 2.9 & \\
\hline $\begin{array}{l}\text { Blue sticky traps } \\
\text { G1 }\end{array}$ & 0.8 & 1.6 & 2.0 & 2.6 & 1.6 & 2.7 & 3.7 & 4.0 & 3.1 & 2.9 & 2.2 & 1.5 & 1.0 & 0.7 & 2.2 & -24.0 \\
\hline $\begin{array}{l}\text { weekly rotation of } \\
\text { compounds G2 }\end{array}$ & 0.8 & 1.4 & 1.8 & 2.4 & 2.0 & 2.4 & 2.0 & 1.6 & 1.5 & 2.0 & 2.0 & 1.2 & 1.0 & 0.8 & 1.6 & -42.6 \\
\hline $\begin{array}{l}\omega \\
\text { Weekly rotation } \\
\text { of compounds in } \\
\text { combination of } \\
\text { traps G3 }\end{array}$ & 0.8 & 1.4 & 1.6 & 2.5 & 0.9 & 1.1 & 1.0 & 0.9 & 1.1 & 1.3 & 1.0 & 0.9 & 0.8 & 0.6 & 1.1 & -59.9 \\
\hline Control G1 & 0.7 & 1.8 & 2.0 & 2.4 & 2.9 & 2.4 & 3.9 & 4.8 & 5.1 & 4.3 & 4.0 & 3.3 & 2.5 & 1.0 & 2.9 & \\
\hline $\begin{array}{l}\text { Blue sticky } \\
\text { trapsG1 }\end{array}$ & 0.6 & 1.8 & 2.0 & 2.4 & 2.0 & 1.6 & 2.9 & 3.8 & 4.1 & 3.3 & 3.0 & 2.3 & 1.5 & 0.9 & 2.3 & -21.4 \\
\hline $\begin{array}{l}\text { weekly rotation of } \\
\text { compoundsG2 }\end{array}$ & 0.7 & 1.8 & 1.6 & 2.0 & 1.4 & 1.3 & 1.6 & 1.2 & 2.0 & 2.5 & 1.8 & 1.0 & 1.2 & 1.0 & 1.5 & -48.7 \\
\hline $\begin{array}{l}\text { Weekly rotation } \\
\text { of compounds in } \\
\text { combination of } \\
\text { trapsG3 }\end{array}$ & 0.6 & 1.7 & 1.8 & 2.0 & 1.0 & 1.0 & 1.2 & 0.9 & 1.0 & 0.8 & 1.0 & 0.8 & 0.7 & 0.6 & 1.1 & -63.5 \\
\hline
\end{tabular}

This results indicate that, using rotation of different compounds and in combination of alternative control way such as blue sticky traps could give successful results in WFT control under greenhouse pepper conditions and reduce damages to pepper flowers resulting from infestation by $F$. occidentalis adults and larval stages especially, in the state of new hybrids production as occurred in the present study under greenhouse conditions in Kaha region, Qalyubia. Where the author found the same which observed by others, thrips feed by piercing plant cells with their mouthparts and sucking out their contents. Damaged plant cells collapse, resulting in deformed plant growth, flower deformation, or silvered patches and flecking on expanded leaves. If thrips feed within developing buds, the damaged cells fail to grow as the leaf or flower expands, resulting in deformed leaves or flowers. WFT feed on petals and pollen resulting in flower buds abort.

In this regard, Frantz and Mellinger (2009) stated that, insecticides applied to peppers affected thrips populations, resulting in average numbers over the 3-week sampling period between approximately 200 thrips per sample in the untreated check and 600 in the gamma-cyhalothrin treated plots. Total thrips populations in plots treated with permethrin were intermediate between these extremes ( 350 per sample). Methoxyphenozide applications did not significantly affect numbers of thrips.

Western flower thrips (WFT) is considered the most destructive insect pest of greenhouse-grown crops due to direct feeding damage to plant 
parts such as foliage and flowers, and indirect damage by vectoring the tospoviruses; impatiens necrotic spot and tomato spotted wilt virus. Furthermore, WFT is difficult to manage in greenhouse production systems As such, the management of WFT involves a holistic or complex approach including the concurrent implementation of scouting, cultural, physical, insecticidal, and biological strategies. It is important that greenhouse producers preserve the longevity of currently existing products by establishing rotation schemes based on different modes of action. In addition, greenhouse producers must utilize sanitation and biological control practices to avoid solely relying on insecticides (Cloyd 2009). In addition, Elimem\& Chermiti (2011) mentioned that, the use of plant extracts is another effective means of controlling WFT. For example, a plant extract-based insecticide including Platycladus orientalis L., Stemona japonica (Kunth), Chenopodium ambrodioides L., and Sophora flavescens (Ait) used in rose crop greenhouses could control WFT with $80 \%$ efficiency.

\section{ACKNOWLEDGEMENTS}

The author are grateful for the assistance provided by Maaly Essa Abdallah, Insect Classification Dept. in thrips identification and BadranAbdel Fatah Badran, Vegetable Pests Research Dept., Plant Protection Research Institutein sampling and investigation.

\section{REFERENCES}

Anonymous (2002): Frankliniella occidentalis diagnostic protocols for regulated pests. OEPP/EPPO Bulletin, 32: 281-292.

Belharrath B., Ben Othman M.N., Garbous B., Hammas Z., Joseph E., Mahjoub M., Sghari R., Siala M., Touayi M., ZaidiH. (1994): La défense des cultures en Afrique du Nord en considérant le cas de la Tunisie. Deutsche Gesellschaft für technische Zusammenarbeit (GTZ), Rossdorf.

Cloyd R. A. (2009): Western Flower Thrips(Frankliniella occidentalis) Management on Ornamental Crop Grown in Greenhouses: Have We Reached an Impasse? Pest Technology 3(1), 1-9@2009 Global Science Books.

Elimem M., Jaime A. Teixeira DA Silva and Brahim Chermiti (2014): Doubleattraction Method to Control Frankliniella occidentalis (Pergande) in Pepper Crops in Tunisia. Plant Protect. Sci., Vol. 50, 2014, No. 2: 90-96.

Elimem M.,and Chermiti B. (2011): Frankliniella occidentalis (Pergande) (Thysanoptera; Thripidae) sensitivity to two concentrations of a herbal insecticide "Baicao 2" in a Tunisian rose crop greenhouse. Floriculture and Ornamental Biotechnology, 5: 68-70.

El-Wakkad M. F. (2007): Ecological and taxonomical studies on thrips in some horticulture fields. Ph.D. Thesis, Fac. of Agric., Cairo Univ., 185 pp. 
Eugene Miliczky and David R. Horton (2011): Occurrence of the Western Flower Thrips, Frankliniella occidentalis, and potential predators on host plants in near orchard habitats of Washington and Oregon (Thysanoptera: Thripidae).J. Entomol. Soc. Brit. Columbia 108, December 2011.

Funderburk Joe, Stuart Reitz, Phil Stansly, Steve Olson, David Sui, Gene McAvoy, Alicia Whidden, Ozan Demirozer, Greg Nuessly, and Norm Leppla (2011): Managing Thrips in Pepper and Eggplant. ENY-658 (IN401), one of a series of the Entomology and Nematology Department, Florida Cooperative Extension Service, Institute of Food and Agricultural Sciences, University of Florida. http://edis.ifas.ufl.edu.

Galen Frantz and H. C. Mellinger (2009): Shifts in western flower thrips, Frankliniella occidentalis (Thysanoptera: Thripidae), Population abundance and crop damage. Florida Entomologist 92(1).

Grasselly D. (1996): Le thrips Frankliniella occidentalis, Les possibilité de lutte. Phytoma-La Défense des Cultures, 483: 61-63.

Hansen, E. A., J. E. Funderburk, S. R. Reitz, S. Ramachandran, J. E. Eger, and $\mathrm{H}$. McAuslane. (2003): Within-plant distribution of Frankliniella species (Thysanoptera: Thripidae) and Orius insidiosus (Hemiptera: Anthocoridae) in field pepper. Environmental Entomology 32: 10351044.

Hoddle M.S., Robinson L., Morgan D. (2002): Attraction of thrips (Thysanoptera: Thripidae and Aeolothripidae) to colored sticky cards in a California avocado orchards. Crop Protection, 21: 383-388.

Ignatowicz, S. (1979): Effect of inorganic salts upon biology and development of acarid mites. III- Effect of relative humidity and mineral salts upon fecundity and longevity of copra mite, Tyrophagus putrescentiae (Schrank) (Acarina, Acaridae). Bull. Entomol. Pol., 49: 577-581.

Kirk W.D.J. (2001): The pest and vector from the West: Frankliniella occidentalis. In: Thrips and tospoviruses.Proceeding of the $7^{\text {th }}$ International Symposium on Thysanoptera. Reggio Calabria, Italy, 27 July 2001. Australian National Insect Collection, Canberra: 33-42.

Kirk W.D.J., Terry L.I. (2003): The spread of the western flower thrips Frankliniella occidentalis (Pergande). Agricultural Forest Entomology, 5: 301-310.

Reda, A. M. Amer; Shalaby, H. H.; Hatem, A. E. and Salem, M.S. (2014): Efficacy of Two Different Plant Extracts on the Toxicity and Biological Aspects of Pectinophora gossypiella (Saunders) Under Laboratory conditions. Egyptian Journal of Biological Pest Control 24(1): 29-35.

Roditakis N.E., Lykouressis D.P., Golfinopoulou N.G. (2001): Color preference, sticky trap catches and distribution of western flower thrips in greenhouse cucumber,sweet pepper and eggplant crops. South-Western Entomology, 26: 227-237. 
Sampson C., Hamilton J.G.C., KirkW.D.J. (2012): The effect of trap colour and aggregation pheromone on trap catch of Frankliniella occidentalis and associated predators in protected pepper in Spain. Integrated Control in Protected Crops, Temperature Climate. IOBC/WPRS Bulletin, 80: 313-318.

Shelton A.M., Nault B.A., Plate J., ZhaoJ. Z. (2003): Regional and temporal variation in susceptibility to lambdacyhalothrin in onion thrips in onion fields in New York. Journal of Economic Entomology, 96: 1843-1848.

Shelton A.M., Zhao J.Z., Nault B.A., Plate J., Musser F.R., Larentzakie E. (2006): Patterns of insecticide resistance in onion thrips (Thysanoptera: Thripidae) in onion fields in New York. Journal of Economic Entomology, 99: 1798-1804.

Tommasini M.G. and S. Maini (2002): Thrips control on protected sweet pepper crops: enhancement by means of Orius laevigatus releases. Australian National Insect Collection CSIRO, 2002 THRIPS AND TOSPOVIRUSES: PROCEEDINGS OF THE $7^{\text {TH }}$ INTERNATIONAL SYMPOSIUM ON THYSANOPTERA

Yang T.; Geert Stoopen; Gerrie Wiegers; Jing Mao; Caiyun Wang; Marcel Dicke aand Maarten A. Jongsma (2012): Pyrethrins Protect Pyrethrum Leaves against Attack by Western Flower Thrips, Frankliniella occidentalis. J Chem Ecol (2012) 38:370-377.

Zepa-Coradini C., Petrescu I., Petolescu C., Pălăgeşiu I. (2010): Frankliniella occidentalis controlling in the cucumbers crops using physicomechanical. Lucrări Ştiinţifice, 53: 292-297

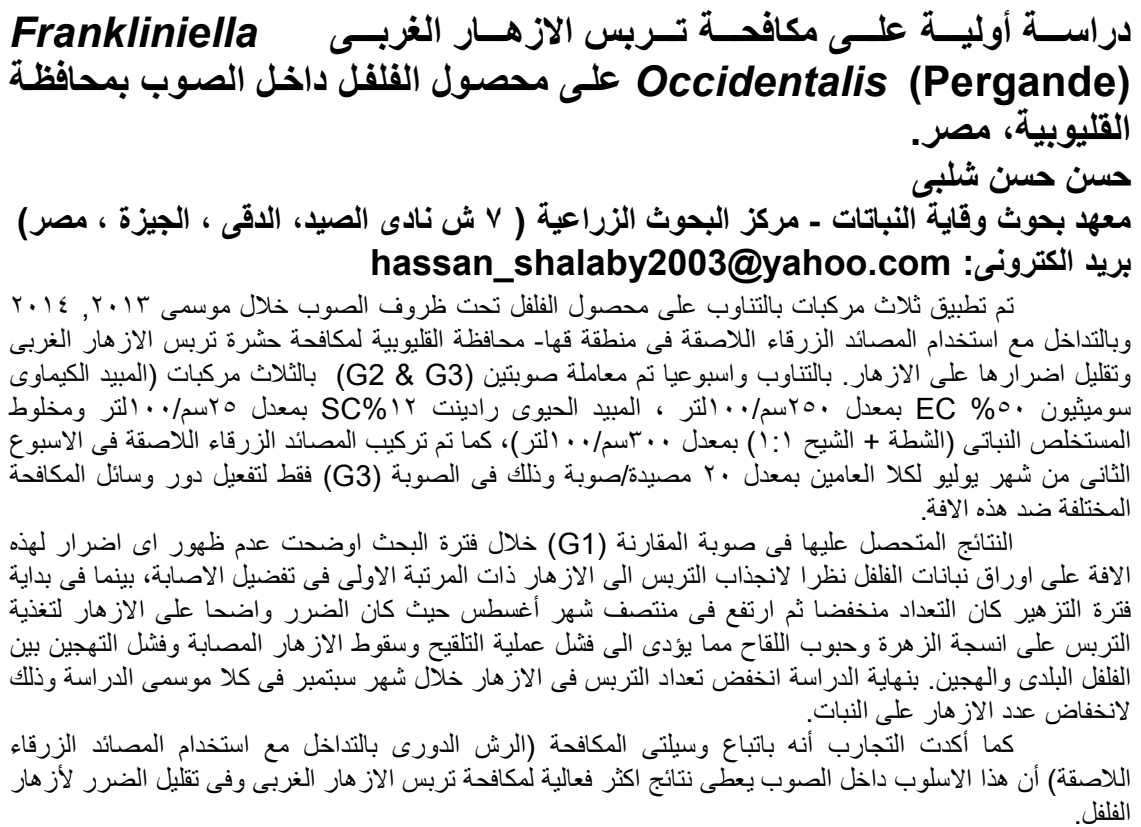

